\title{
VARIATION IN OZONE CONCENTRATION AND VOLUMETRIC ACTIVITIES OF RADON PROGENY ON THE CURONIAN SPIT
}

\author{
V. Valuntaitéa, D. Jasaitis ${ }^{a}$, R. Girgždienè $\dot{e}^{\mathrm{a}, \mathrm{b}}$, and A. Girgždys ${ }^{\mathrm{a}}$ \\ a Vilnius Gediminas Technical University, Sauletekio 11, LT-10223 Vilnius, Lithuania \\ E-mail: vaida.valuntaite@vgtu.lt \\ b State Research Institute Center for Physical Sciences and Technology, Savanoriu 231, LT-02300 Vilnius, Lithuania
}

Received 13 February 2013; revised 17 June 2013; accepted 20 June 2013

\begin{abstract}
This paper presents the study of variation in ozone concentration and volumetric activities of radon decay products as well as their relationship at the ground level of the atmosphere on the Curonian Spit. The simultaneous measurements of the ground-level ozone concentration and volumetric activity of radon progeny gave a possibility to identify the presence of a breeze phenomenon on the Curonian Spit during an extreme weather event in summer when ozone concentration exceeded the target value of $120 \mu \mathrm{g} \mathrm{m}^{-3}$ that can have a negative impact on human health. The evident influence of wind direction on ozone concentration and volumetric activity of radon progeny was estimated.
\end{abstract}

Keywords: radon decay products, volumetric activity, ozone concentration, meteorological parameters, breeze

PACS: 92.60.Sz, 91.10.Vr, 23.60.+e, 89.40.Dd

\section{Introduction}

Ground-level ozone $\left(\mathrm{O}_{3}\right)$ is a major constituent of atmospheric smog that can cause human health problems. Ozone is mainly produced by photochemical reactions between nitrogen oxides $\left(\mathrm{NO}_{x}\right)$ and volatile organic compounds (VOCs) in the presence of sunlight [1, 2]. The ozone level in a given area depends not only on the ozone source intensity, but also on the atmospheric stability. Atmospheric stability, which is characterized by temperature change with height, controls the amount of vertical air mixing. Strong atmospheric stability tends to reduce the mixing of groundlevel ozone and ozone-forming emissions. During temperature inversions, the air higher in the atmosphere is warmer than the air near the ground level. Such situation can have influence on the increase of ozone concentration during daytime and on its decrease during night time. The local meteo-climatic conditions and the mixing properties of the lower atmosphere, which determine atmospheric stability, can be evaluated by monitoring radon and its short-lived decay products (radon progeny) [3-6].

The ground-level ozone concentration shows seasonal and clear diurnal fluctuations. The ozone concentration in Lithuania mostly varies up to $100-120 \mu \mathrm{g} \mathrm{m}^{-3}$ [阴, and the level of $120 \mu \mathrm{g} \mathrm{m}^{-3}$ is observed only during less than $10 \%$ of time per year and it is usually the result of long-range transport of polluted air [7]. It is also estimated $[8$, 9] that during the sea breeze circulation ozone concentration can rise up to a high level. The longterm investigations of ozone concentration on the Baltic Sea coast showed its clear dependence on 
wind direction and speed [10, 11]. However, sea breezes are not common phenomena in the region of the Baltic Sea [12]. It is possible to determine a breeze not only by the precise measurement of wind parameters but also by the behaviour of radon and its progeny.

Radon and its progeny have a clear daily variation corresponding to the diurnal low atmosphere layer mixing. When mixing starts from late morning, volumetric activity decreases, and when mixing becomes weak in the afternoon, the volumetric activity value increases. The measurements of radon and its progeny and wind intensity give information about the strength of atmospheric stability that consequently affects air pollution by ozone.

Meanwhile, radon concentration is dominant at the ground level at night due to a decrease of vertical air mixing. However, it is effective only over the land, since radon gas emanates from soil where it forms as a result of decay of ${ }^{226} \mathrm{Ra}$. The concentration of radon and its progeny over the water surface is very low. Therefore, higher concentration over the sea was found only in case of air advection from the land [13]. The radon concentration in soils is about $10^{5} \mathrm{~Bq} \cdot \mathrm{m}^{3}$ [14], whereas over the oceans it is only about $2 \mathrm{~Bq} \cdot \mathrm{m}^{3}[15]$.

The aim of the study was to determine relationship between variations in ozone concentration and volumetric activities of radon progeny in the air on the Curonian Spit.

\section{Methods}

Investigations were carried out in the Juodkrante $\left(55^{\circ} 32^{\prime} \mathrm{N}\right.$ and $21^{\circ} 06^{\prime} \mathrm{E}$ ) surroundings (Curonian Spit) in July 2010. The study site is located on the coast of the Baltic Sea (about $20 \mathrm{~m}$ from the sea and $1.5 \mathrm{~km}$ from the Curonian Lagoon) (Fig. 1).

Ozone concentration and volumetric activity of radon decay products and meteorological parameters in the ambient air were continuously measured by averaging the data of 5 minutes. Ozone concentration was measured with an analyser ML9811 (Fig. 2). The operation of this analyser is based on the principle of ultraviolet absorption. The range of ozone measurements is $0-2000 \mu \mathrm{g} \mathrm{m}^{-3}$, and sensitivity is $2 \mu \mathrm{g} \mathrm{m}^{-3}$. The air was sucked through a Teflon tube at a flow rate of $1.61 \mathrm{~min}^{-1}$.

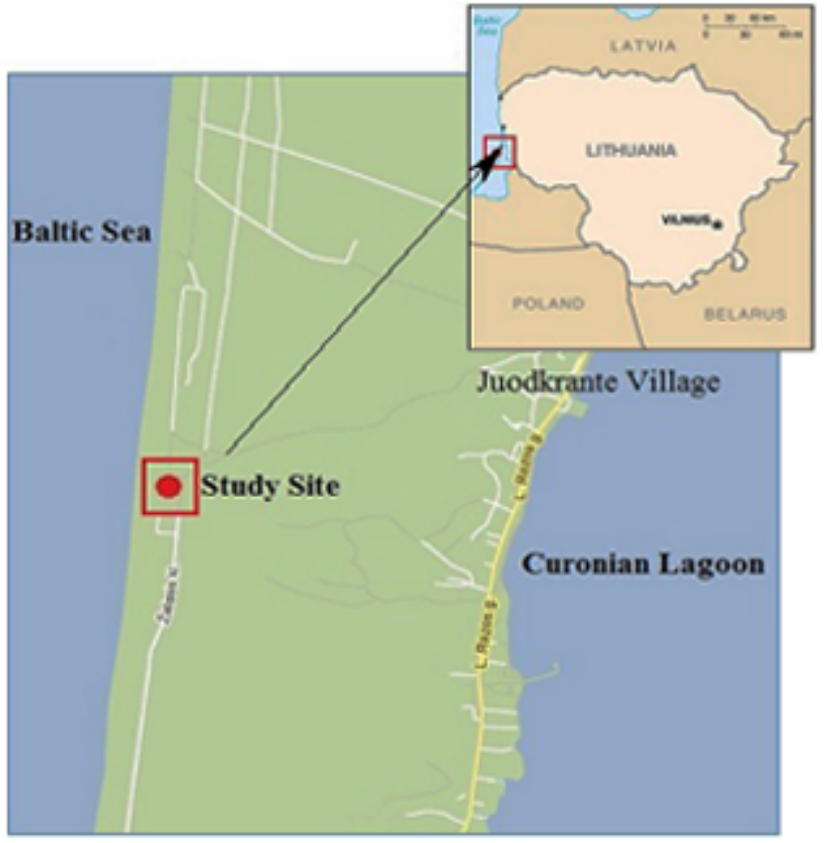

Fig. 1. Location of the study site.

The equipment to measure radon decay products [16] consists of the filtration device with a radiometer GM-45 and the air volume meter with a pump. The radiometer GM-45 is a light and extremely sensitive detector of ionizing radiation. It contains a Geiger-Müller counter, which is sensitive to alpha, beta, and gamma radiation. The RAD (Radiation Acquisition and Display) program is included in this device. The usage of the RAD program enabled data to be stored and transferred into MS Excel program, where they could be processed.

Electronic stopwatches TS-ED1 were set, and the time of air suction and of turning on the filter band were programmed. Having set the time when the measurements were automatically carried out, the device could operate continuously. The measurement error was not higher than $6 \%$.

The meteorological parameters (temperature, relative humidity, wind speed and direction) were measured by PC Radio Weather Station. The temperature in the range of $\left(-30{ }^{\circ} \mathrm{C}-+70{ }^{\circ} \mathrm{C}\right)$ was measured with the accuracy of $\pm 1{ }^{\circ} \mathrm{C}$, the wind speed in the interval of $0-60 \mathrm{~m} \mathrm{~s}^{-1}$ was measured with the accuracy of $\pm 0.3 \mathrm{~m} \mathrm{~s}^{-1}$, the wind direction resolution was 5 degrees, the relative humidity range was from 20 to $100 \%$, and resolution was $1 \%$. The temperature, relative humidity, wind speed and direction sensors were located at the $3.5 \mathrm{~m}$ height at about $20 \mathrm{~m}$ from the Baltic Sea. 


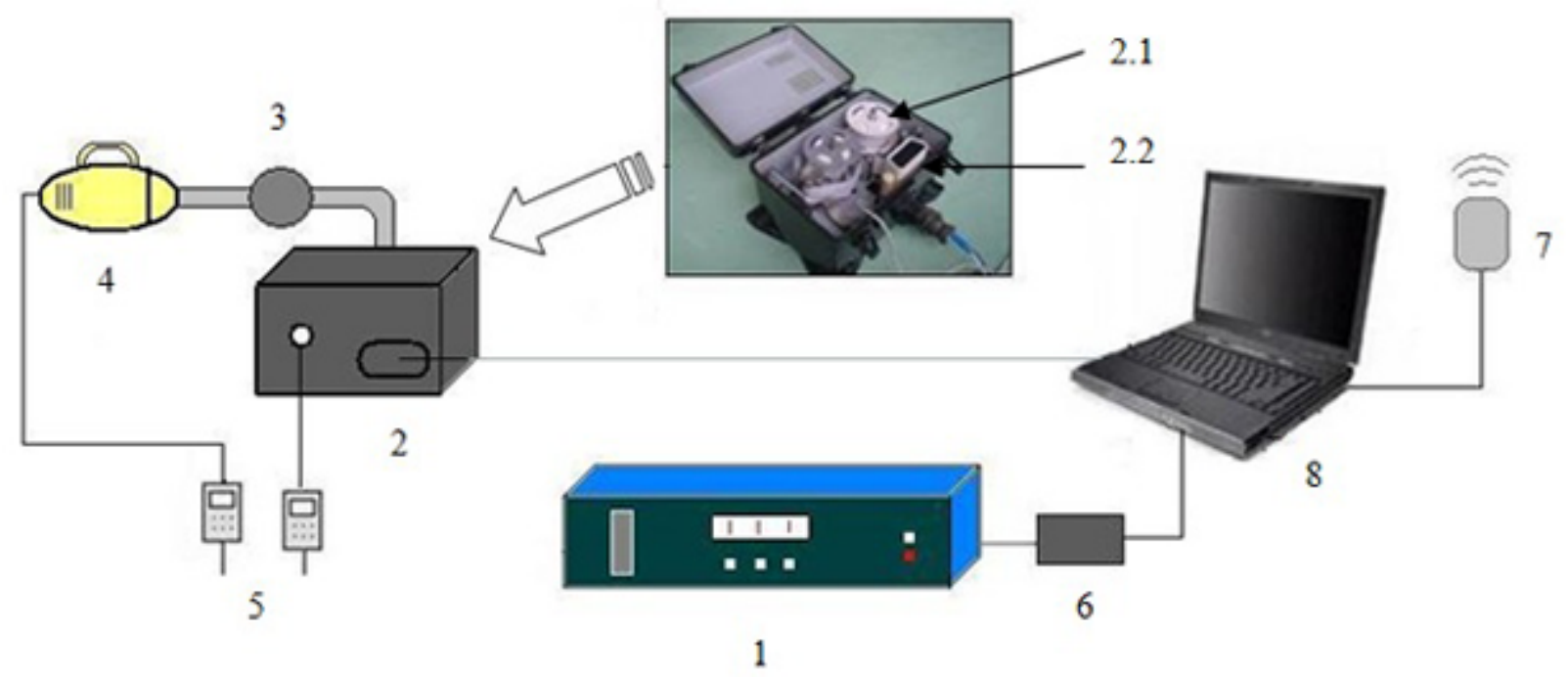

Fig. 2. Experimental set-up: 1 ozone analyser, 2 filtration device (2.1 filter band, 2.2 radiometer), 3 air volume meter, 4 air pump, 5 stopwatches, 6 converter, 7 weather station, 8 PC.

\section{Results}

Ozone concentration exceeded the level of $120 \mu \mathrm{g} \mathrm{m}^{-3}$ several days during July 2010. One of episodes was observed during 11-17 July. Extreme climatic conditions were dominating during this period. The territory of Lithuania was influenced by the anticyclone, and air temperature reached $34^{\circ} \mathrm{C}$ and relative humidity varied from 25 to $100 \%$. The low-speed winds were predominating during these days, and the wind speed higher than $5 \mathrm{~m}^{-1}$ was recorded only during $2 \%$ of time.

In summer, wind direction from the sea is most frequently observed during the daytime and the wind from the continent during night time, as was observed (Fig. 3) at the coastal station in Preila $(\mathrm{Cu}-$ ronian Spit), which is located about $9 \mathrm{~km}$ from our study site.

However, an atypical situation in respect of wind direction dominated during 11-17 July. The wind

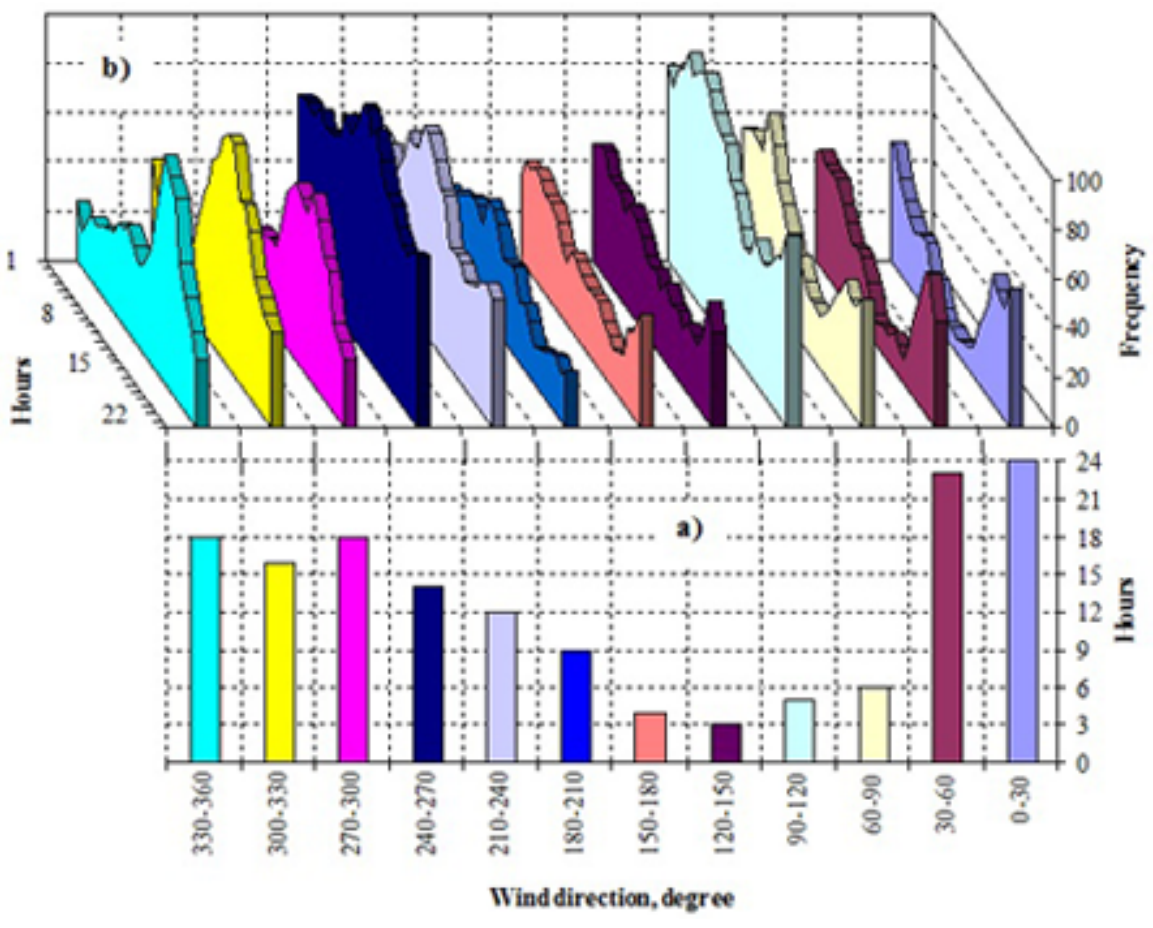

Fig. 3. The frequency of wind direction during the warm period at the station in Preila: (a) frequency of measured wind during 24 hours from separate sectors, (b) hours when the wind from the corresponding sector was observed most frequently. 
from the continent, i. e. south-eastern and eastern (39 and 18\% of the observation time, respectively), was measured, while the winds from the Baltic Sea (west-northern) blew relatively seldom (30\% of the time).

During this period, ozone concentration and volumetric activities of radon decay products showed pronounced diurnal variations (Fig. 4). Volumetric activities of radon short-lived decay products varied from 2 to $16 \mathrm{~Bq} \mathrm{~m}^{-3}$ and the measured average volumetric activity of radon decay products was $7 \mathrm{~Bq} \mathrm{~m}^{-3}$.

The maximum average ozone concentration was found in the afternoon, while the minimum value was observed at night and early in the morning. The ozone diurnal course is associated with diurnal variations in the vertical air mixing intensity as well as potential local photochemical ozone production and decay [17]. These processes are the most effective during daylight hours when temperature is the highest and relative humidity is low. At night, not intensive vertical air mixing results in slower ozone transport and dominates its decay. Volumetric activities of radon progeny start to increase at $10-11$ p.m. and reach maximum at 5-6 a.m. just before the sunrise, meanwhile the minimum values are observed at about noon. This might be explained by the fact that variation in volumetric activities of radon decay products is influenced by the inten- sity of air mixing. In the daytime, the sun heats up the earth surface and the positive temperature gradient occurs above the surface. In the evening, when the heat of the sun is not so effective, the positive temperature gradient is constantly shifting towards the negative gradient. At this time, increase in volumetric activities of radon decay products continues and reaches the maximum value. Such conditions were observed on 11-14 July when the anticyclone dominated over the Lithuanian territory. Only on 15-16 July the cyclone approached the territory of Lithuania. The previous long-term continuous measurements on the seashore at Preila and Rūgšteliškès (continent) monitoring stations [10, 11] showed that the ozone diurnal course was significantly more expressed under the conditions of the anticyclone than of the cyclone. On the continent, ozone concentration may decrease down to $1-2 \mu \mathrm{g} \mathrm{m}^{-3}$ at night and increase up to $120-160 \mu \mathrm{g} \mathrm{m}^{-3}$ during the day, and on the seashore this variation is significantly smaller.

The volumetric activities of radon decay products decreased during the rainy period. This is because radon decay products are usually associated with aerosol particles, which are always in the air, and the fall washes them out from the air.

It was established that the influence of the rainy period, i. e. increase of relative humidity in the air, on variations in ozone concentration was lower than

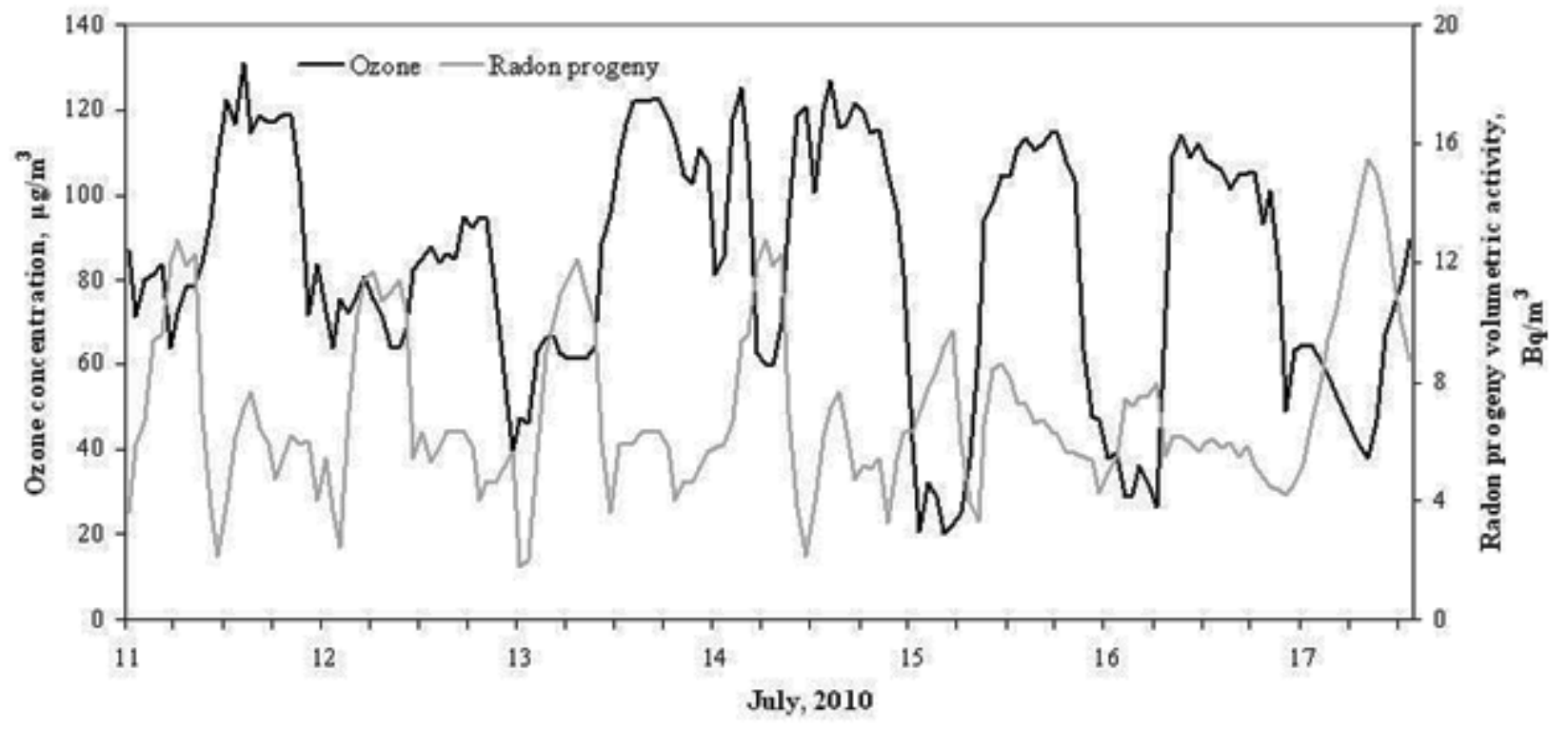

Fig. 4. The time course of ozone concentration and radon volumetric activity. 
on volumetric activities of radon decay products. The negative correlation between ozone concentration and relative humidity was observed.

An analysis of relationship between ozone concentrations, volumetric activities of radon short-lived decay products, and wind speed showed that higher ozone concentration was recorded when wind speed was higher. One of the reasons for such ozone increase may be the higher values of wind speed and ozone concentration observed in the daytime. The relationship between ozone concentration and wind speed showed that the maximum ozone concentration was also observed when wind speed did not exceed $3 \mathrm{~m} \mathrm{~s}^{-1}$, i. e. when the local photochemical production of ozone could occur. The minimum ozone concentration was recorded during windless nights; the obtained average ozone concentration under such conditions was $36 \mu \mathrm{g} \mathrm{m}^{-3}$. Volumetric activities of radon decay products decreased with theincrease of wind speed because radon gas is better dispersed in the atmosphere. However, it was determined that in this case concentration of radon decay products was more influenced by wind direction (low-speed winds dominated during the study).
The influence of wind direction and speed on variation in ozone concentration (Fig. 5) and volumetric activities of radon decay products (Fig. 6) was estimated.

The maximum average value of ozone concentration was obtained when wind direction was from the sea, and the minimum value was found when the wind was from the continent. The higher values of ozone concentration when the wind is blowing from the sea are usually determined by a slower rate of ozone decay to the surface of water. The dry deposition rate for ozone is $0.53-1.1 \mathrm{~mm} \mathrm{~s}^{-1}$ to the surface of water, $7 \mathrm{~mm} \mathrm{~s}^{-1}$ to the soil, and it may even exceed $21 \mathrm{~mm} \mathrm{~s}^{-1}$ to a forest [18].

A different situation was observed with radon progeny activity. The maximum of volumetric activity of radon short-lived products was estimated when the wind was from the continent, and the minimum was measured when the wind was from the sea, because the largest source of radon is soil.

As it has been mentioned above, local winds, i. e. breezes, is not a frequent phenomenon in the region of the Baltic Sea and the processes of air mass transport mostly hide their influence on

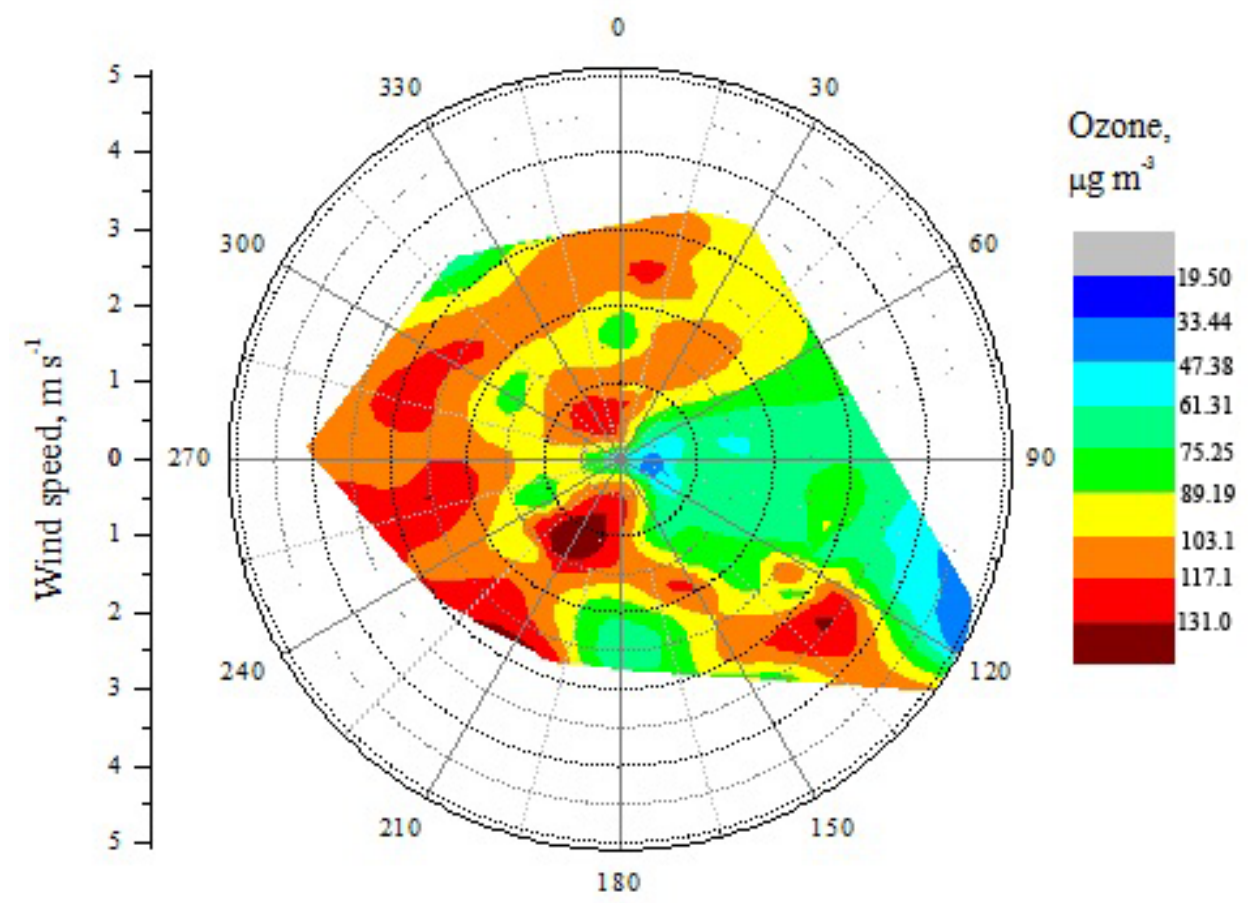

Fig. 5. Relationship between ozone concentration and different wind speed and direction during 11-17 July 2010. 


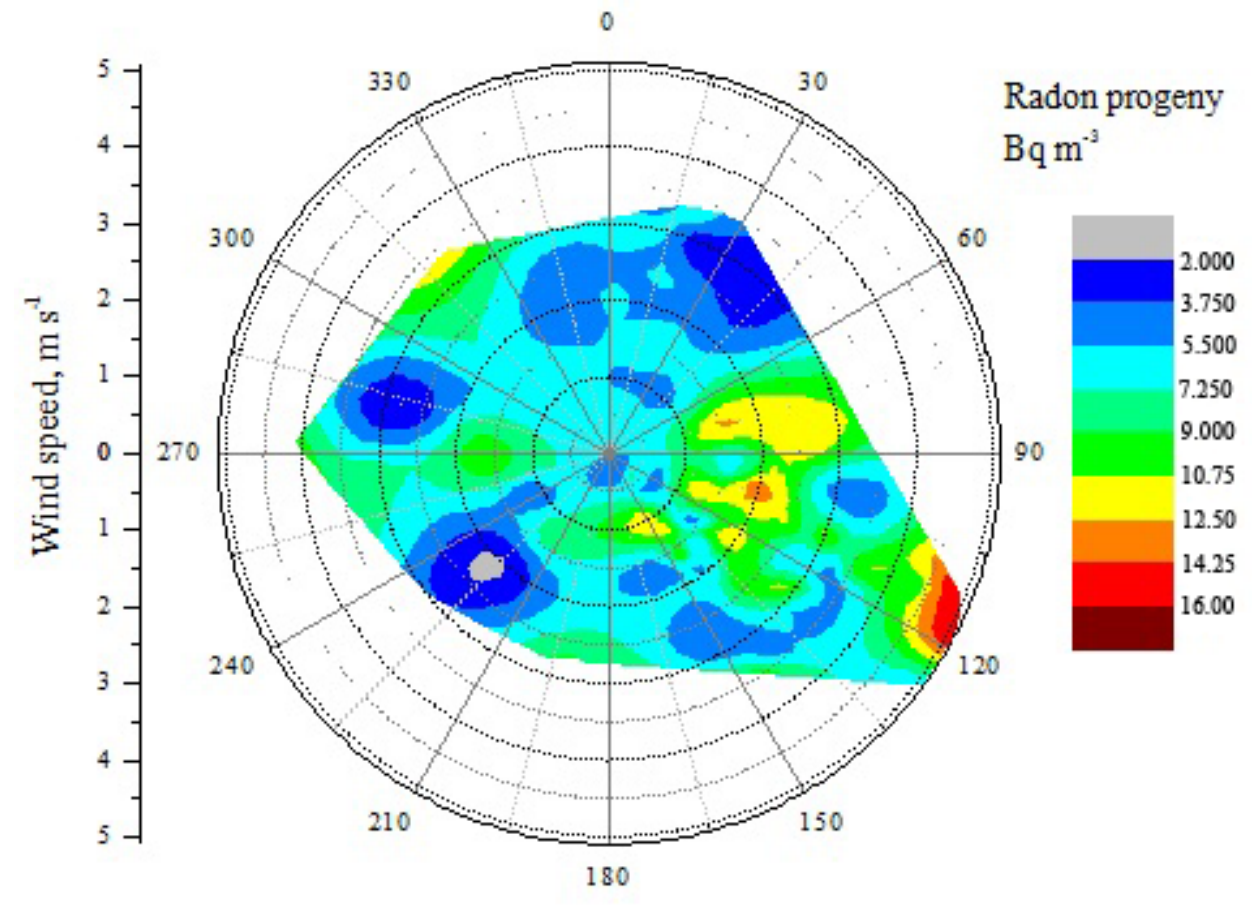

Fig. 6. Relationship between volumetric activity of radon decay products and different wind speed and direction during 11-17 July 2010.

the level of pollution. Breezes are variable winds changing their direction twice a day along the coastlines of seas. During daylight hours, the land gets heated up faster than the water surface and a lower pressure zone forms above the land. Therefore, a daytime breeze blows from water to the heated coast. At night, the reverse process occurs: the land gets cool quicker than the water surface and the wind direction changes from the land to the water. Breezes may form on the Baltic seashore under the conditions of the anticyclone, when the wind is weak.

Based on the analysis of variations in wind direction and speed, relative humidity, and temperature, it was established that during several days of the study, i. e. from 11 to 14 of July, breeze was present on the seashore of the Curonian Spit. During this period, the variations in ozone concentration and volumetric activities of radon decay products coincided with the daily periodic change of wind direction. Such variation in ozone and radon concentrations on 11-14 of July may be explained by the influence of the breeze. Ozone concentration was approximately $10-15 \mu \mathrm{g} \mathrm{m}^{-3}$ higher than during the days when breeze circulation was not observed.

\section{Conclusions}

1. A clear relationship between ozone concentration and volumetric activities of radon progeny variations was observed in the air on the Curonian Spit, especially during the anticyclone, and their pronounced inverse diurnal courses were observed. Ozone concentration and volumetric activities of radon decay products decreased during the rainy period. However, the influence of the increase of relative humidity in the air was lower on variations in ozone concentration than on volumetric activities of radon decay products.

2. The evident influence of wind direction on the time course of ground-level ozone concentration and volumetric activity of radon progeny was estimated under the coastal conditions. The simultaneous measurements of ozone concentration and volumetric activity of radon progeny gave the possibility to identify the presence of a breeze phenomenon on the Curonian Spit in summer during extreme weather events.

3. It was found that under extreme weather conditions, the ground-level ozone concentration on the coast of the Baltic Sea could exceed $120 \mu \mathrm{g} \mathrm{m}^{-3}$, i. e. the level that can have a negative impact on human health. 


\section{References}

[1] J. Zheng, J.L. Swall, W.M. Cox, and J.M. Davis, Interannual variation in meteorologically adjusted ozone levels in the eastern United States: A comparison of two approaches, Atmos. Environ. 41(4), 705-716 (2007).

[2] J.M. Godowitch, A.B. Gilliland, R.R. Draxler, and S.T. Rao, Modeling assessment of point source $\mathrm{NO}_{x}$ emission reductions on ozone air quality in the eastern United States, Atmos. Environ. 42(1), 87-100 (2008).

[3] Z. Zhang, F. Wang, F. Costabile, I. Allegrini, F. Liu, and W. Hong, Interpretation of ground-level ozone episodes with atmospheric stability index measurement, Environ. Sci. Pollut. Res. 19(8), 3421-3429 (2012).

[4] M.C. Subbaramu and K.G. Vohra, Investigations on radioactive equilibrium in the lower atmosphere between radon and its short-lived decay products, Tellus 21(3), 395-403 (2010).

[5] V. Pont and J. Fontan, Correlation between continental air mass and ozone concentrations, J. Geophys. Res. D 105(14), 17699-17707 (2000).

[6] L. Sesana, L. Barbieri, U. Facchini, and G. Marcazzan, ${ }^{222}$ Radon as a tracer of atmospheric motions: a study in Milan, Radiat. Prot. Dosim. 78(1), 65-72 (1998).

[7] R. Girgzdiene, S. Bycenkiene, and A. Girgzdys, Variations and trends of AOT40 and ozone in the rural areas of Lithuania, Environ. Monit. Assess. 127(1-3), 327-335 (2007).

[8] J.A. Adame, E. Serrano, J.P. Bolivar, and B.A. De La Morena, On the tropospheric ozone variations in a coastal area of southwestern Europe under a mesoscale circulation, J. Appl. Meteorol. Climatol. 49(4), 748-759 (2010).

[9] D.K. Martins, R.M. Stauffer, A.M. Thompson, T.N. Knepp, and M. Pippin, Surface ozone at a coastal suburban site in 2009 and 2010: Relationships to chemical and meteorological pro- cesses, J. Geophys. Res. D 117(5) (2012), http:// dx.doi.org/10.1029/2011JD016828.

[10] R. Girgzdiene and A. Girgzdys, The influence of wind parameters on the ozone concentration variation on the Baltic Sea coast, Environ. Chem. Phys. 23(3-4), 112-117 (2001).

[11]R. Girgzdiene, A. Girgzdys, M. Frolova, and I. Lyulko, Ozone at two stations on the Baltic seashore, Environ. Chem. Phys. 22(2), 59-64 (2000).

[12]H. Bergström, Boundary-layer modelling for wind climate estimates, Wind Eng. 25(5), 289-299 (2001).

[13] S. Whittlestone, Radon measurements as an aid and interpretation of atmospheric monitoring, J. Atmos. Chem. 3(1), 187-201 (1985).

[14]I.A. Ghita and A. Vasilescu, Radon assessment with solid-state nuclear track detectors in Bucgarest and its surrounding region, Rom. Rep. Phys. 63(4), 940-947 (2011).

[15] B. Burnett, T. Nelson, R. Corbett, L. Robinson, J. Weaver, J.E. McKisson, and D. Lane-Smith, Improvements in the Measurement of Rn-222 in Natural Waters, in: Proc. 44th Annual Conference on Bioassay, Analytical, and Environmental Radiochemistry (Albuquerque, New Mexico, 1520 November 1998), http://www.nucfilm.com/ burnett_98.pdf

[16] D. Jasaitis and A. Girgždys, Hourly measurement method for radon progeny volumetric activity in air, J. Environ. Eng. Landsc. Manag. 15(3), 158165 (2007).

[17]L.M. David and P.R. Nair, Diurnal and seasonal variability of surface ozone and NOx at a tropical coastal site: Association with mesoscale and synoptic meteorological conditions. J. Geophys. Res. D 116(10303); http://dx.doi. org/10.1029/2010JD015076 (2011).

[18] M.W. Gallagher, K.M. Beswick, G. McFiggans, H. Coe, and T.W. Choulartonn, Ozone dry deposition velocities for coastal waters, Water Air Soil Pollut. 1, 233-242 (2001).

\title{
OZONO KONCENTRACIJOS IR RADONO TRUMPAAMŽIŲ SKILIMO PRODUKTŲ TÜRINIO AKTYVUMO KAITA KURŠIIU NERIJOJE
}

\author{
V. Valuntaité ${ }^{a}$, D. Jasaitis ${ }^{a}$, R. Girgždienè $\dot{e}^{a, b}, A$. Girgždys $^{a}$ \\ ${ }^{a}$ Vilniaus Gedimino technikos universitetas, Vilnius, Lietuva \\ ${ }^{\mathrm{b}}$ Valstybinis moksliniu tyrimu institutas Fiziniu ir technologijos mokslų centras, Vilnius, Lietuva
}

\section{Santrauka}

Tirta ozono koncentracijos ir radono skilimo produktų tūrinio aktyvumo kaita bei jų tarpusavio ryšys atmosferos priežemio sluoksnyje Kuršių nerijoje. Tuo pačiu metu atlikti ozono koncentracijos ir radono skilimo produktų tūrinio aktyvumo matavimai leido 2010 m. liepos mèn. nustatyti brizo reiškini pajūrio zonoje. Nustatyta, kad esant ekstremalioms oro sąlygoms ozono koncentracija Baltijos jūros pakrantejje viršija $120 \mu \mathrm{g} \mathrm{m}^{-3}$, t. y. lygi, kuris gali žalingai veikti žmogaus sveikatą. Vertinant meteorologinių parametrų itaką ozono koncentracijos ir radono skilimo produktų tūrinio aktyvumo eigai priežemio ore nustatyta, kad didžiausią poveikị turèjo vejo kryptis. 